\title{
Availability of Physical Facilities in Colleges of Education in South East Nigeria
}

\author{
Dr. Gladys Uzoechina
}

Chukwuemeka Odumegwu Ojukwu University, Igbariam Campus

\begin{abstract}
The study was set to investigate the availability of physical facilities in Nigerian colleges of Education. The study was limited to public and private colleges of Education in South East Nigeria. Researcher- developed instrument titled 'Checklist on Availability of Physical Facilities' (CAPF) was used for data collection. The instrument was validated by two experts and also tested for reliability using spearman rho and cronbach alpha which yielded high index of 0.95. Population of the study consisted of 13845 respondents made up of the principal officers and students of the colleges studied. Sample of 1,425 was drawn from the population using proportionate stratified random sampling technique and used for the study. One research question and one null hypothesis guided the study while data collected were analyzed using frequency counts and percentages. Hypothesis was tested using chi-square. Among the findings made were that physical facilities were available but not adequate in the colleges of education. Recommendations were made one of which is that adequate physical facilities should be provided to colleges of Education by relevant authorities.
\end{abstract}

Keywords: Facility; Availability; Lecture Halls; Classrooms; Administrative Blocks; Students Hostels; Football Fields and Lawns.

\section{Introduction}

In any teaching and learning environment, buildings, playgrounds and mobile structures are provided to enhance efficiency. These are referred to as school physical facilities. Osahen (1998) defined school physical facilities as tangible structures, which serve educational purpose. They stand for the physical expression of the existence of any school as school programmes are expressed through them. Similarly, physical facilities according to Ehiametalor (2001) are "operational inputs of every institutional programme". For effective teaching and learning situation, physical facilities and educational goals should be viewed as being closely inter-woven and inter-independent. These physical facilities represent a learning environment, which has a tremendous impact on the comfort, safety and performance of the learner.

Colleges of Education are among institutions of learning formally designated to provide teacher education. In Nigeria, teacher education is given a major emphasis in all educational planning because of its importance. Colleges of Education will only carry out effective teacher education upon successful implementation of relevant programmes. Physical facilities ought to be available as they play major roles in the implementation process. Availability of physical facilities refers to provision made in this regard to the colleges for effective teaching and learning. Provision of physical facilities should be among the very first preparation necessary for opening a new school. Adesina (1980) corroborated this view by insisting that proprietors opening new schools should where to existing regulations on provision of physical facilities.

The National Commission for Colleges of Education (NCCE) among several other responsibilities usually carry out a resource visit to any new College of Education whether public or private to ascertain the extent of availability of physical facilities for its programmes. Consequently, proprietors of both public and private colleges of education ought to ensure that provisions are made for needed physical facilities as availability of physical facilities such as lecture halls, classrooms, administrative blocks, students hostels, football fields, lawns, paths among others is a pre-requisite for approval of any college of Education in Nigeria.

Physical facilities should be adequately provided to create favourable environment for learning. National Commission for Colleges of Education (2002) set out criteria for determining adequacy of facilities. For instance, a standard chemistry laboratory is meant to serve only 50 students at a time and would be considered inadequate when utilized by more than that number of students. Notably, availability of physical facilities in the Colleges of Education does not guarantee their adequacy and effective utilization and maintenance. It is then necessary to assess them based on the factors raised as inadequacy; poor utilization and maintenance constitute serious hindering factors in effective teaching and learning. There are basically two reasons why physical facilities are important in schools.

Firstly, use of dilapidated school buildings and grounds that are unsafe or unsuitable for modern functional education purposes will lead to the production of mediocre. Such colleges cannot attain excellence in teaching and learning since teachers cannot discover giftedness in non-functional college environment. Secondly, modernization of college facilities is a prerequisite in this era of modern technology and science. Enya (2008) stated that physical facilities ought to be kept in good conditions through regular and periodic maintenance. There is then the need to investigate on the extent physical facilities are maintained in Nigeria Colleges of Education. According to Okoro (2006) Provision of fund for plant maintenance should be a priority in the whole college business be it public or private. The National Commission for Colleges of Education (NCCE), also places a priority on provision of fund for plant maintenance while approving any new College of Education whether public or private.

Similarly, Okoro (2008) maintained that Provision of adequate physical facilities, which should be effectively 


\section{International Journal of Science and Research (IJSR) \\ ISSN (Online): 2319-7064}

Index Copernicus Value (2013): 6.14 | Impact Factor (2014): 5.611

utilized and maintained as and when due has remained a condition for accrediting the courses of any college of education. It seems there are differences between public and private colleges of Education in availability of physical facilities. It is against this background, therefore, that this study is focused to investigate the availability of physical facilities in both public and private colleges of Education in the South East Nigeria.

\section{Statement of the Problem}

In the last two decades, the cost of financing education in Nigeria had increased and the non-corresponding expansion in facilities, equipment and material resources has resulted in gradual but general collapse of the education system, (Akilaiya, 2001). Colleges of Education in Nigeria especially in the south east geo-political zone presently and in all ramifications appear to have physical facility-related problems. Observation indicates that virtually all the Colleges of Education have overcrowded hostels, unconducive classrooms as most floors and walls are found dilapidated and hazardous. Similarly, doors and windows appear to be out of use and create a situation of insecurity while some college buildings are usually seen in bad condition with either blown-off roofs, broken walls, leaking roof or both which constitute danger to the lives of the users and invariably pose a threat to the programmes of the colleges. Again, most college environment appears untidily kept suggesting conservancy problems. Students are often seen struggling or queuing to use some facilities which is indicative of a problem of adequacy of available facilities.

It is sad to hear the often-negative opinion of most members of the public about some graduates of colleges of education lack basic knowledge and experience. The situation is disturbing and calls for thorough investigations into both the remote and immediate causes as no meaningful academic work in may be attainable without functional facilities. This problem called for serious concern hence the need to determine the actual state of needed physical facilities in the colleges. Thus, the problem of this study is to investigate the availability of physical facilities in the Colleges of Education in south eastern Nigeria.

\section{Purpose of the study}

The main purpose of this study is to ascertain the availability of physical facilities in Colleges of Education in Nigeria. Specifically, the study was set to identify available physical facilities in the Colleges of Education in South Eastern Nigeria.

\section{Research Questions}

In carrying out this study, one research question was posed.

1. What physical facilities are available in Colleges of Education in South Eastern Nigeria?

\section{Hypotheses}

To facilitate the investigation, one null hypothesis was tested at 0.05 level of significance.

1. There is no significance difference between public and private Colleges of Education in availability of physical facilities.

\section{Method}

The study was carried out the South East geo-political zone of Nigeria. Descriptive survey design was adopted in the study. The population of the study consisted of 13845 respondents made up of 7 Provosts, 7 Registrars, 7 Directors of work, 7 Bursars, 40 Deans, 152 Heads of Department and 13,845 students. The entire population of the provosts, Registrars, Bursars, Directors of work, totaling 28 was involved in the study. Similarly, sample was not drawn from the 40 Deans of school and 152 Heads of Department. They were all used for the study. However, sample was drawn from 200 level students considered more convenient for the study as 100 level students were new in the college while 300 level students might not be readily available due to the busy nature of their level. Proportionate stratified random sampling procedure was the technique for the selection of sample students. $30 \%$ of the population of each stratum was selected to realize 1205 as sample. Asika(2006) stated that $30 \%$ sample was adequate for a study of this nature. The study therefore made use of 1425 respondents.

Researcher-developed instrument titled „Checklist on availability of physical facilities ${ }^{e e}$ was used for data collection. The instrument contained a preliminary section and a section created for the purpose of eliciting needed information. The instrument was validated by two experts in Educational Management and Policy and Measurement and Evaluation, all of Nnamdi Azikiwe University, Awka. As a result of their comments, some original items in the instruments were dropped. The was determined for reliability using a test retest carried out on 30 respondents who were not part of the study. Spearman rho was also used to assess the reliability of the instrument. The instrument yielded alpha of 0.95 which is quite high

Each of the colleges of education under study was visited by the researchers to complete the checklists while with the help of seven research assistants; the questionnaire was administered on the respondents who were expected to complete them. The entire questionnaire totaling 1425 were completed and returned. Data were analyzed using frequency and percentage counts for research question and the hypothesis was tested using chi-square.

Decision Rule: Based on the analysis, the decision rule was stated thus:

Frequency and percentage were used in determining the research question. Item was considered available if it scored up to $50 \%$.

\section{Results}

In this section, the data collected from the field for answering the research question and testing hypothesis were presented in tables to highlight the findings.

Research Question One: What physical facilities are available in Colleges of Education in South Eastern Nigeria?

Data Collected were analyzed on individual cluster basis using frequency and percentages as presented in table one.

\section{Volume 5 Issue 2, February 2016}




\section{International Journal of Science and Research (IJSR) \\ ISSN (Online): 2319-7064}

Index Copernicus Value (2013): 6.14 | Impact Factor (2014): 5.611

Table 1: Summary Table on the Availability Of Facilities

\begin{tabular}{|c|c|c|c|c|c|}
\hline S/No & Item & $\begin{array}{c}\text { No of Physical } \\
\text { facilities Available. }\end{array}$ & $\%$ & $\begin{array}{c}\text { No of Physical Facilities } \\
\text { Not Available. }\end{array}$ & $\%$ \\
\hline 1 & Staff Facilities & 33 & 94.3 & 2 & 5.7 \\
\hline 2 & Sporting & 34 & 54.0 & 29 & 46.0 \\
\hline 3 & Lecturing facilities. & 25 & 89.3 & 3 & 10.7 \\
\hline 4 & Laboratory facilities & 32 & 76.2 & 10 & 23.8 \\
\hline 5 & Library & 14 & 100 & 0 & 0 \\
\hline 6 & Demonstration and Exhibition Facilities & 25 & 44.6 & 31 & 55.4 \\
\hline 7 & Hostel & 13 & 62.0 & 8 & 38.1 \\
\hline 8 & Refectory & 12 & 57.1 & 9 & 42.9 \\
\hline 9 & Medical Facilities & 6 & 85.7 & 1 & 14.3 \\
\hline 10 & Religious Facilities & 3 & 21.4 & 11 & 78.3 \\
\hline 11 & Water/Power & 25 & 89.3 & 3 & 10.7 \\
\hline 12 & Security & 7 & 100 & 0 & 0 \\
\hline 13 & Conservancy & 4 & 57.1 & 3 & 42.9 \\
\hline 14 & General & 4 & 57.1 & 3 & 42.9 \\
\hline
\end{tabular}

Table shows that out of the 14 main facilities listed, only two were not available as indicated by the decision score of $50 \%$. Those not available were numbers 6 (Demonstration and Exhibition facilities) and 10 (Religious facilities). Result then indicates that physical facilities were available in the colleges.

$\mathrm{HO}_{1}$ : There is no significant difference between the mean rating of public and private colleges of Education in availability of physical facilities.

Table V: Chi-square $\left(\mathrm{X}^{2}\right)$ Summary of Public and Private Colleges of Education rating on availability of Physical

\begin{tabular}{|c|c|c|c|}
\hline facilities. \\
\hline Institution & Available & Not Available & Total \\
\hline $\begin{array}{c}\text { Public colleges of } \\
\text { Education }\end{array}$ & $\begin{array}{c}75 \\
(69.6)\end{array}$ & $\begin{array}{c}26 \\
(31.3)\end{array}$ & 101 \\
\hline $\begin{array}{c}\text { Private colleges of } \\
\text { Education }\end{array}$ & 63 & 36 & 99 \\
\hline Total & $\mathbf{1 3 8}$ & $(30.6)$ & \\
\hline
\end{tabular}

Therefore $\mathrm{X}^{2}=\sum(0-\mathrm{E})^{2} ; \quad \mathrm{P}<0.05$

$$
\mathrm{E} \quad \mathrm{DF}=1
$$

The calculated value of chi-square $=8.84$, while the critical value of chi square $=3.84$. The calculated chi value is greater than critical value; therefore the null hypothesis is not accepted.

\section{Summary of Major Findings}

Based on the analysis of data collected for this study, the major finding of the study was that physical facilities are available in public and private colleges of education in the South East Nigeria.

\section{Discussion of Findings}

The findings of the study were discussed based on the research question and null hypothesis that guided the study. Table 1 provided answer to the research question which was posed to ascertain available physical facilities in the colleges of education. From the analysis, 2 out of 14 cluster items listed were not available. The facilities not available are in the area of demonstration/exhibition facilities and religious facilities. These facilities ought to be available considering their importance in teaching and learning.
However, results revealed that physical facilities were available in the Colleges of Education since 38 items representing $76 \%$ of the items listed were available. This collaborates with Adebiyi (2004) who opined that physical facilities were available in Nigerian Colleges of Education. The non acceptance of the hypothesis indicated that physical facilities were available to both public and private college of Education but with some disparities. It then implies that Education managers in both public and private colleges of Education though aware of the role physical facilities play in teaching and learning, allow disparities to exist in the provision of the facilities.

\section{Conclusion}

Based on the analysis of data for this study, the researchers concluded that physical facilities are available in the colleges of Education in the South East Nigeria as non available ones are insignificant though necessary in teaching and learning.

\section{Recommendations}

Based on the revelations of the study after extensive discussions of the results, the researchers recommended as follows:

1) The few physical facilities that are not available should be provided in all the colleges by relevant authorities in order not to undermine their enormous contributions to educational development.

2) Students and staff should be given proper orientation on how to handle college facilities through regular seminars and workshops.

\section{References}

[1] Adebiyi, Y. (2004). Equipping Nigerian schools for productivity in the education sector. Teachers and Parents Magazine. July-September, P. 9.

[2] Adesina, S. (1980). Some aspects of school management. Ibadan: Board publications Ltd.

[3] Ajegbu, I.C. (1999). Factors associated with the administrative effectiveness of principals of secondary schools in Onitsha Education Zone of Anambra State. 


\section{International Journal of Science and Research (IJSR) \\ ISSN (Online): 2319-7064}

Index Copernicus Value (2013): 6.14 | Impact Factor (2014): 5.611

Unpublished M.Ed dissertation, Nnamdi Azikiwe University.

[4] Akilaiya, O. (2001). Educational administration. Onitsha: Linul publishers.

[5] Anene, A. (2002). Implementing education policies. Insight newspaper, Jan, 27 P. 5

[6] Asika, N. (2006). Research methodology in the behavioural sciences. Lagos: Longman.

[7] Ebru, I.R. (2005). Effective maintenance of physical facilities. A paper presented to the conference of Head Teachers of Ebonyi South Education Zone held at Ebonyi Hotels. Afikpo. April 13-15.

[8] Ehiametalor, E.T. (2001). School facilities: Management practice in Nigeira. In N.A. Nwagwu, E.T. Eliametalor, M.A. Ogunu and Mon Nwadiani (Eds). Current Issues in Educational Management. Benin City. NAEAP.

[9] Enya, O. (2004). Improving the aesthetics of the school through maintenance of School Plant. A paper presented at the conference of Head Teachers of Primary Schools in Nigeria. Journal of Empirical Studies in Psychology and Education. 1(2), 60-64.

[10] Ezeuwa, L. (2005). Availability and utilization of financial Resources in Ebonyi State Secondary Schools. Unpublished M.Ed dissertation: Ebonyi State University, Abakaliki.

[11] Facina, A.S. (2005). The school plant maintenance. Journal of Educational Administration and Planning 5 (1).

[12] Federal Republic of Nigeria (2004). National Policy on Education. Lagos: NERDC.

[13] Mba, F. (2003). Effective School Management. A workshop paper presented at the workshop of Education Secretaries and Supervisors of Education held at Eagle royal Hotel, Abakaliki. April 13-15.

[14] Mgbodile, T.O (2004). Fundamentals in educational administration and planning. Nsukka: Magnet Business Enterprise.

[15] National Commission for Colleges of Education (2002). Minimum standard for Nigeria certificate in education, $3^{\text {rd }}$ Edition. Abuja: NCCE Press.

[16] Ndu, A.N., Ocho, L.O. and Okeke, B.S. (1997). Dynamics of educational administration and management: The Nigerian Perspective. Awka: Mcks Publishers Ltd.

[17] Nwagwu, N.A. (1978). Primary school administration. Lagos: Macmillan Nigeria Publishers Ltd.

[18] Nwagwu, N.A., Ehiametalor, E.T., Ogunu, M.A. and Nwadiani, MON (2002). Current issues in educational management in Nigeria. Benin City: Ambik Press ltd.

[19] Obi, E. (2006). Practicum in school organization. Enugu: Computer Age Publishers.

[20] Ogonor, B.O. and Sanni, G.A. (2001). Maintenance of Secondary School Facilities in Midwestern Nigeria. In N.A. Nwangwu, E.T. Ehiametalor, M.A. Ogunu and MON Nwadiani (Eds) current issues in educational management in Nigeria. Benin City: Ambike Press ltd.

[21] Okoro, S. (2006). School Plant Management. A conference paper presented at the conference of primary school Head teachers in Ebonyi north Educational Zone at ugwuachara. March 13.

[22] Olaitan, S.A and Nwoke, R. (1998). Educational research. Nsukka: Meks.
[23] Olatunbosun, P.I. (2005). School Plant Management in a Deregulated Education System. Unpublished work on Funding of Education in Nigeria.

[24] Osahen, U (1988). Facilities management in schools. In MON Nwadiani (ed). Education Management for subsaharan Africa. Benin City: Nigeria Society for Education Planners.

[25] Uche, E.U. (1990). Availability and Utilization of Instructional Resources in the Secondary Schools in Enugu State. College of Education, Eha-Amufu Journal of Education Vol 2.

[26] Ugo, I. (2006). Provision and Maintenance of Physical Facilities in Private Secondary Schools in Enugu State. Unpublished M.Ed Dissertation. Enugu State University. 